\title{
Sesquiterpenoids, Triterpenoids, and Flavonoids from the Fruits of Schinus molle
}

\author{
Masateru ONO ${ }^{1 *}$, Masakazu Yamashita ${ }^{1}$, Kaori Mori ${ }^{1}$, Chikako MasuoKA ${ }^{1}$, Masashi Eto ${ }^{1}$, Junei KinJo ${ }^{2}$, \\ Tsuyoshi IKeda ${ }^{3}$, Hitoshi Yoshimitsu ${ }^{4}$, and Toshihiro Nohara ${ }^{4}$ \\ ${ }^{1}$ School of Agriculture, Tokai University, 5435 Minamiaso, Aso, Kumamoto 869-1404, Japan \\ ${ }^{2}$ Faculty of Pharmaceutical Sciences, Fukuoka University, 8-19-1 Nanakuma, Jonan-ku, Fukuoka 814-0180, Japan \\ ${ }^{3}$ Faculty of Medical and Pharmaceutical Sciences, Kumamoto University, 5-1 Oe-honmachi, Kumamoto 862-0973, Japan \\ ${ }^{4}$ Faculty of Pharmaceutical Sciences, Sojo University, 4-22-2 Ikeda, Kumamoto 860-0082, Japan
}

Received April 16, 2008; Accepted June 24, 2008

Twelve sesquiterpenoids, one of which was a new compound, six tirucallane-type triterpenoids, and four flavonoids were isolated from the fruits of Schinus molle L. (Anacardiaceae). Their chemical structures were determined on the basis of spectroscopic data and X-ray analysis. Among them, three flavonoids exhibited almost identical antioxidative activity as that of $\alpha$-tocopherol by the ferric thiocyanate method. In addition, one flavonoid showed a stronger radical-scavenging effect on 1,1-diphenyl-2-picrylhydrazyl than that of $\alpha$-tocopherol.

Keywords: Schinus molle, Anacardiaceae, sesquiterpenoid, triterpenoid, flavonoid, antioxidative activity, radical-scavenging effect

\section{Introduction}

Schinus molle L. (Anacardiaceae) is native to South and Central America, but has been acclimated to most of the tropical and subtropical areas of the world. The fruits of this plant are used as a pepper substitute and a source of vinegar and beverages. Furthermore, the fruits, leaves, and sap of the trunk are used as traditional medicines in Peru (Olfasson et al., 1997). With regard to the chemical constituents of the fruits, tirucallane- and euphane-type triterpenoids, an aromadendrane-type sesquiterpenoid, and a biflavonoid have been previously reported (Terhune et al., 1974; PozzoBalbi et al., 1978; Olfasson et al., 1997; Yueqin et al., 2003). In the course of our studies on the constituents of Peruvian plants (Ono et al., 2008), we have investigated the constituents of the fruits of $S$. molle. Here we report the isolation and structural elucidation of a new sesquiterpenoid along with 11 known sesquiterpenoids, six known tirucallane-type triterpenoids, and four known flavonoids, as well as the antioxidative activity of the flavonoids.

\section{Materials and Methods}

General experimental procedures Optical rotations were

*To whom correspondence should be addressed.

Email: mono@agri.u-tokai.ac.jp measured with a JASCO DTP-1000 KUY digital polarimeter (JASCO, Tokyo, Japan). Proton $\left({ }^{1} \mathrm{H}\right)$ - and carbon-13 $\left({ }^{13} \mathrm{C}\right)$ nuclear magnetic resonance (NMR) spectra were recorded using a JEOL Alpha 500 spectrometer (JEOL, Tokyo, Japan). Mass spectra were obtained on a JEOL JMS-DX-303HF instrument (JEOL). Visible absorptions were measured with a JASCO UV-530 UV/vis spectrometer (JASCO). Column chromatography was carried out over silica gel 60 (Merck, Art. 1.07734 and Art. 1.09385; Merck, Darmstadt, Germany), Diaion HP20 (Mitsubishi Chemical Industries Co., Ltd., Tokyo, Japan), MCI gel CHP20P (Mitsubishi Chemical Industries Co., Ltd.), Sephadex LH-20 (Pharmacia Fine Chemicals, Uppsala, Sweden), Chromatorex ODS (Fuji Silysia Chemical Ltd., Aichi, Japan), and Bio-Beads SX2 (BIO-RAD Laboratories, Hercules, CA, USA). High performance liquid chromatography (HPLC) separation was run on a Micro pump LC-10AS (Shimadzu, Kyoto, Japan) with a RI-Detector RID-10A (Shimadzu). For HPLC column chromatography, a COSMOSIL 5C18 AR-II column (Nacalai Tesque, Inc., Kyoto, Japan, $250 \mathrm{~mm} \times 20 \mathrm{~mm}$ i. d.) was used. Linoleic acid was purchased from Tokyo Kasei Kogyo Co. (Tokyo, Japan) and the other reagents were purchased from Nacalai Tesque, Inc.

Plant material Dried fruits of Schinus molle L. were purchased in October (1993) from Fundation Pala la Inves- 
tigation Technologica del Recurso Agrobiologico Andio, a research institute of Andes Agricultural Bioresources in Peru, and identified by Sokurates Shiota, Executive Director, Fundation Pala la Investigation Technologica del Recurso Agrobiologico Andio.

Extraction and isolation The dried and powdered fruits of $S$. molle $(720 \mathrm{~g})$ were extracted with methanol $(\mathrm{MeOH})$ $(1000 \mathrm{ml} \times 6)$ under reflux for $2 \mathrm{~h}$, and the solvent was removed under reduced pressure to give a syrup $(148.7 \mathrm{~g})$. The $\mathrm{MeOH}$ extract was chromatographed over a Diaion HP20 column $(50 \% \mathrm{MeOH}, \mathrm{MeOH}$, acetone) to give Fraction 1 (70.72 g), Fraction 2 (47.59 g), and Fraction 3 (19.60 g). Fraction 2 was treated with hexane $(755 \mathrm{ml})$ to yield a hexanesoluble fraction $(15.50 \mathrm{~g})$ and a hexane-insoluble fraction (30.42 g). Chromatography of the hexane-insoluble fraction over a silica gel column [Art. 1.07734, $\mathrm{CHCl}_{3}-\mathrm{MeOH}-\mathrm{H}_{2} \mathrm{O}$ (14:2:0.1, 8:2:0.2, 7:3:0.5, 6:4:1, 0:1:0)] furnished Fractions 4 - 13. Fraction 4 (4366 mg) was subjected to silica gel column chromatography [Art. 1.09385, hexane-acetone (20:1, 10:1, 5:1, 3:1, 1:1, 0:1), MeOH] to afford Fractions 14 - 20. Fraction $17(553 \mathrm{mg})$ was separated by chromatography over a Chromatorex ODS column ( $80 \% \mathrm{MeOH}, 90 \% \mathrm{MeOH}$, $\mathrm{MeOH}$ ) to give Fractions 21 - 24. High performance liquid chromatography (COSMOSIL 5C18 AR-II, 95\% MeOH) of Fraction 23 gave $4(131 \mathrm{mg})$. Fraction $18(918 \mathrm{mg})$ was separated by chromatography over a Chromatorex ODS column ( $90 \% \mathrm{MeOH}, \mathrm{MeOH})$ to furnish $18(290 \mathrm{mg})$ and Fractions 25 - 27. Chromatography of Fraction 26 (262 mg) over a silica gel column [Art. 1.09385, $\mathrm{CHCl}_{3}, \mathrm{MeOH}$ ] gave 3 ( 25 $\mathrm{mg}$ ). Fraction 6 (3502 mg) was separated by chromatography over a Chromatorex ODS column $(70 \% \mathrm{MeOH}, \mathrm{MeOH})$ to give Fractions 28 - 35. Fractions 29 (79 mg), 30 (21 mg), 32 $(93 \mathrm{mg})$, and $34(78 \mathrm{mg})$ were each subjected to HPLC under similar conditions $(70 \% \mathrm{MeOH})$ to Fraction 23 to give $\mathbf{1 6}$ $(29 \mathrm{mg})$ and $\mathbf{1 1}(12 \mathrm{mg})$ from Fraction 29, $12(8 \mathrm{mg})$ from Fraction 30, 1 (6 mg) and $\mathbf{1 4}(61 \mathrm{mg})$ from Fraction 32, and $9(20 \mathrm{mg})$ and $\mathbf{1 0}(15 \mathrm{mg})$ from Fraction 34. Fraction 7 (2480 $\mathrm{mg}$ ) was separated by chromatography over a Chromatorex ODS column (60\% MeOH, 70\% MeOH, $80 \% \mathrm{MeOH}, 90 \%$ $\mathrm{MeOH}, \mathrm{MeOH}$ ) to yield Fractions 36 - 44. Fractions 37 (41 $\mathrm{mg}), 40(85 \mathrm{mg})$, and $41(87 \mathrm{mg})$ were each subjected to HPLC under the same conditions as for Fraction 29 to yield $16(11 \mathrm{mg})$ from Fraction 37, $1(41 \mathrm{mg})$ and $\mathbf{1 4}(8 \mathrm{mg})$ from Fraction 40, and $\mathbf{1 0}(18 \mathrm{mg})$ and $\mathbf{9}(25 \mathrm{mg})$ from Fraction 41. Similar HPLC (65\% MeOH) of Fraction 39 (79 mg) to Fraction 23 furnished $13(21 \mathrm{mg})$. Fraction $8(4757 \mathrm{mg})$ was subjected to Sephadex LH-20 column chromatography $(\mathrm{MeOH})$ to give 22 (1442 mg). Fraction 9 (4329 mg) was separated by chromatography over a Chromatorex ODS column (50\% $\mathrm{MeOH}, 60 \% \mathrm{MeOH}, 70 \% \mathrm{MeOH}, 80 \% \mathrm{MeOH}, 90 \% \mathrm{MeOH}$,
$\mathrm{MeOH})$ to give Fractions 45 - 51. Fraction $46(223 \mathrm{mg})$ and Fraction $50(115 \mathrm{mg})$ were each subjected to HPLC [COSMOSIL 5C18 AR-II, Fraction 46 (40\% MeOH), Fraction 50 $(70 \% \mathrm{MeOH})]$ to give $7(17 \mathrm{mg})$ from Fraction 46 and 8 (10 $\mathrm{mg})$ from Fraction 50. Fraction $48(2140 \mathrm{mg})$ was successively subjected to silica gel [Art. $1.09385, \mathrm{CHCl}_{3}-\mathrm{MeOH}-$ $\left.\mathrm{H}_{2} \mathrm{O}(20: 1: 0,10: 1: 0,14: 2: 0.1,6: 4: 1,0: 1: 0)\right]$ and MCI gel CHP20P $\left(\mathrm{H}_{2} \mathrm{O}, \mathrm{MeOH}\right.$, acetone) column chromatography to yield $21(29 \mathrm{mg})$. Fraction $11(1503 \mathrm{mg})$ and Fraction $12(1595 \mathrm{mg})$ were each subjected to Sephadex LH-20 column chromatography $(\mathrm{MeOH})$ to furnish $19(35 \mathrm{mg})$ from Fraction 11 and Fraction 52 and Fraction 53 from Fraction 12. Chromatography of Fraction $53(240 \mathrm{mg})$ over a silica gel column [Art. 1.09385, $\mathrm{CHCl}_{3}-\mathrm{MeOH}-\mathrm{H}_{2} \mathrm{O}$ (14:2:0.1)] furnished $20(129 \mathrm{mg})$. The hexane-soluble fraction was separated by chromatography over a silica gel column [Art. 1.09385, hexane-acetone $(20: 1,15: 1,10: 1,5: 1,3: 1,1: 1)]$ to give Fractions 54 - 61. Fraction $55(121 \mathrm{mg})$ was successively subjected to silica gel [Art. 1.09385, hexane-acetone (30:1, 20:1, 10:1, 5:1, 3:1, 1:1)] and Bio-Beads SX2 [hexaneacetone (1:1)] column chromatography, and similar HPLC $(93 \% \mathrm{MeOH})$ to Fraction 23 to yield $15(16 \mathrm{mg})$. Fraction $57(1464 \mathrm{mg})$ was successively subjected to Chromatorex ODS column chromatography $(50 \% \mathrm{MeOH}, 60 \% \mathrm{MeOH}$, $70 \% \mathrm{MeOH}, 80 \% \mathrm{MeOH}, 90 \% \mathrm{MeOH}, \mathrm{MeOH})$ and HPLC under the same conditions as for Fraction 29 to give 14 (13 $\mathrm{mg})$ and $10(39 \mathrm{mg})$. Fraction $58(280 \mathrm{mg})$ was subjected to HPLC under the same conditions as for Fraction 29 to furnish $16(32 \mathrm{mg}), 2(11 \mathrm{mg})$, and Fraction 62. Fraction 62 (58 mg) was separated by chromatography over a silica gel column [Art. 1.09385, hexane-acetone (10:1, 5:1)] to give 1 (34 mg). Fraction 59 (501 mg) was successively subjected to Chromatorex ODS column chromatography $(60 \% \mathrm{MeOH}$, $70 \% \mathrm{MeOH}, 80 \% \mathrm{MeOH}, 90 \% \mathrm{MeOH}, \mathrm{MeOH})$ and HPLC under the same conditions as for Fraction 29 to give $\mathbf{6}$ (8 $\mathrm{mg}), \mathbf{5}$ (9 mg), $\mathbf{1 7}$ (10 mg), and $\mathbf{1 8}$ (108 mg).

Acetylation of 1 Compound $\mathbf{1}(5 \mathrm{mg})$ in $\mathrm{Ac}_{2} \mathrm{O}$-pyridine $(1: 1,1 \mathrm{ml})$ was left to stand at room temperature overnight. After removal of the reagent under a stream of $\mathrm{N}_{2}$, the residue was partitioned between ether and $\mathrm{H}_{2} \mathrm{O}$. The ether layer was concentrated to give $\mathbf{1 a}(5 \mathrm{mg})$.

Single crystal X-ray analysis of 3 A colorless needle crystal having approximate dimensions of $0.10 \times 0.20 \times 1.00$ $\mathrm{mm}$ was mounted on a glass fiber. All measurements were made on a Rigaku RAXIS RAPID imaging plate area detector (Rigaku Co., Tokyo, Japan) with graphite monochromated $\mathrm{Mo}-\mathrm{K} \alpha$ radiation. The data were collected at a temperature of $23 \pm 1^{\circ} \mathrm{C}$ to a maximum $2 \theta$ value of $55.0^{\circ}$. The structure was solved by a direct method (SHELXS) (Sheldrick, 1990) and hydrogen atoms were placed at the calculation. A full-matrix 
least-squares technique was used with anisotropic thermal parameters for non-hydrogen atoms and a riding model was used for hydrogen atoms. All calculations were performed using SHELXL (Sheldrick and Schneider, 1997).

Antioxidative activity by the ferric thiocyanate method The antioxidative activity of the test sample was measured using the previously described ferric thiocyanate method (Kikuzaki and Nakatani, 1993). A mixture of 2.51\% linoleic acid ethanol (EtOH) solution $(0.80 \mathrm{ml}), 0.05 \mathrm{M}$ phosphate buffer $(\mathrm{pH} 7.0,1.60 \mathrm{ml})$, EtOH $(0.60 \mathrm{ml})$, and $\mathrm{H}_{2} \mathrm{O}(0.80 \mathrm{ml})$ was added to $10 \mathrm{~mm}$ EtOH solution $(0.20 \mathrm{ml})$ of each sample in a vial with a cap and placed in the dark at $40^{\circ} \mathrm{C}$ to accelerate the oxidation. At intervals during the incubation, this assay solution $(0.05 \mathrm{ml})$ was diluted with $75 \% \mathrm{EtOH}(4.85 \mathrm{ml})$, which was followed by adding $30 \%$ ammonium thiocyanate $(0.05 \mathrm{ml})$. Precisely $6 \mathrm{~min}$ after the addition of $0.02 \mathrm{~m}$ ferrous chloride in $3.5 \%$ hydrochloric acid $(0.05 \mathrm{ml})$ to the reaction mixture, the absorbance of the developed red color was measured at $500 \mathrm{~nm}$.

Assay of scavenging effect on 1,1-diphenyl-2-picrylhydrazyl (DPPH) The method of Uchiyama et al. (1968) was applied in a slightly modified manner. The EtOH solution $(1.00 \mathrm{ml})$ of each test sample was added to a mixture of $0.1 \mathrm{M}$ acetic acid buffer (pH 5.5, $1.00 \mathrm{ml})$ and $0.5 \mathrm{~mm} \mathrm{DPPH} \mathrm{EtOH}$ solution $(0.50 \mathrm{ml})$ in a test tube and left standing at room temperature for $30 \mathrm{~min}$. The absorbance of the resulting solution was measured at $517 \mathrm{~nm}$. The control sample was prepared from the mixture containing all ingredients except a test sample. The scavenging effect on DPPH was expressed as follows: $\Delta$ O. D. $=$ O. D. of control - O. D. of sample. $\alpha$-Tocopherol was used as a standard sample. Results presented are the means of two experiments.

\section{Results and Discussion}

The $\mathrm{MeOH}$ extract of the fruits of $S$. molle was successively subjected to Diaion HP20, silica gel, Chromatorex ODS, Sephadex LH-20, MCI gel CHP20P and Bio-Beads SX2 column chromatography, as well as HPLC on ODS, to yield 22 compounds: 12 sesquiterpenoids $(\mathbf{1}, \mathbf{2}, 7$ - 16), six tirucallane-type triterpenoids $(3-6,17,18)$, and four flavonoids (19 - 22).

Structure elucidation of $\mathbf{1}$ - $\mathbf{2 2}$ Compounds $\mathbf{7}$ - 22 were identified as teuclatriol (7) (Bruno et al., 1993), 10-epiteuclatriol (8) (Bruno et al., 1993), teucladiol (9) (Bruno et al., 1993), 4 $\beta, 6 \beta$-dihydroxy- $1 \alpha, 5 \beta(H)$-guai-9-ene (10) (Mahmoud, 1997), 1 $\beta, 6 \alpha$-dihydroxy-7-epi-eudesm-3-ene

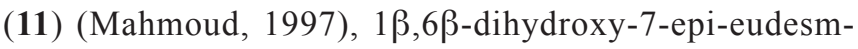
3-ene (12) (Mahmoud, 1997), oplodiol (13) (Takahashi and Takani, 1976), isocalamediol (14) (Nawamaki and Kuroyanagi, 1996), $\alpha$-cadinol methyl ether (15) (Dupré et al., 1991), oplopanone (16) (Herz and Watanabe, 1983), 3 $\beta$-hydroxy-8,24-tirucalladien-21-oic acid (17) (Badria et al., 2003), 3 $\alpha$-hydroxy-8,24Z-tirucalladien-26-oic acid (18) (Olfasson et al., 1997), engeletin (19) (Silva et al., 1997), quercetin 3-O-rhamnoside (20) (Harbone and Mabry, 1982), agathisflavone (21) (Chari et al., 1977), and 2,3,2",3"-tetrahydroamentoflavone (22) (Ahmad et al., 1981), based on comparisons of their physical and spectral data with those in the literature, although ${ }^{1} \mathrm{H}$ - and ${ }^{13} \mathrm{C}-\mathrm{NMR}$ spectral data in pyridine- $d_{5}$ of 7 - 14 and $\mathbf{1 6}-\mathbf{1 8}$ and ${ }^{13} \mathrm{C}$-NMR data of $\mathbf{1 5}$ have not been reported in the literature (Fig. 1, Tables $1-5$ ).

Compound 1 was obtained as a colorless syrup, $[\alpha]_{\mathrm{D}}^{22}+$ $21.7^{\circ}\left(c=5.3, \mathrm{CHCl}_{3}\right)$, and it exhibited an $[\mathrm{M}+\mathrm{Na}]^{+}$ion peak at $\mathrm{m} / \mathrm{z} 261$ in the positive fast atom bombardment mass spectrum (FAB-MS) and an $[\mathrm{M}-\mathrm{H}]^{-}$ion peak at $\mathrm{m} / \mathrm{z} 237$ in the negative FAB-MS. The molecular formula of 1 was determined to be $\mathrm{C}_{15} \mathrm{H}_{26} \mathrm{O}_{2}$ by high-resolution (HR)-negative FABMS ( $m / z 237.1860, \Delta+0.6 \mathrm{mmu})$. The ${ }^{1} \mathrm{H}-\mathrm{NMR}$ spectrum of 1 showed signals due to two tertiary methyl groups $(\delta 1.62$, $1.25)$, two secondary methyl groups $[\delta 0.91(\mathrm{~d}, J=6.5 \mathrm{~Hz})$, $0.90(\mathrm{~d}, J=6.5 \mathrm{~Hz})]$, and one oxygenated methine proton $[\delta$ $4.17(\mathrm{~d}, J=4.5 \mathrm{~Hz})]$. The ${ }^{13} \mathrm{C}$-NMR spectrum of $\mathbf{1}$ showed 15 carbon signals, which were elucidated as signals due to two oxygenated quaternary carbons $(\delta 74.3,73.3)$, one oxygenated methine carbon $(\delta 76.3)$, four methine carbons $(\delta 69.1$, $53.3,38.7,33.3)$, four methylene carbons ( $\delta 48.8,37.9,24.5$, $20.7)$, and four methyl carbons ( $\delta 26.6,22.4,21.2,20.4)$ using the distortionless enhancement by polarization transfer (DEPT) method. These ${ }^{1} \mathrm{H}$ - and ${ }^{13} \mathrm{C}$-NMR signals (Tables 1 and 2) were assigned with the aid of ${ }^{1} \mathrm{H}-{ }^{1} \mathrm{H}$ correlation spectroscopy (COSY), heteronuclear multiple-quantum coherence (HMQC), and heteronuclear multiple-bond correlation (HMBC) spectra, and the planar structure of $\mathbf{1}$, which was a guaiane-type sesquiterpenoid, could be determined by these observations (Fig. 2). A key HMBC correlation between H-6 and $\mathrm{C}-10$ indicated that an epoxy bridge was located between C-6 and C-10. Furthermore, ordinary acetylation of $\mathbf{1}$ with acetic anhydride and pyridine gave a monoacetyl derivative (1a), which was a colorless syrup, of $\mathbf{1}$. The signal of H-6 in the ${ }^{1} \mathrm{H}-\mathrm{NMR}$ spectrum of $1 \mathrm{a}$ exhibited no acetylation shift, whereas the signal due to $\mathrm{C}-4$ in the ${ }^{13} \mathrm{C}-\mathrm{NMR}$ spectrum of 1a, in comparison with that of $\mathbf{1}$, indicated a downfield shift. Thus, the epoxy bridge between C- 6 and C-10 was established and $\mathrm{H}-1 / \mathrm{H}-5$ was assumed to have a cis-configuration by forming the epoxy bridge. In the difference nuclear Overhauser effect (NOE) and nuclear Overhauser and exchange spectroscopy (NOESY) spectra of $\mathbf{1}$, NOEs were observed between the respective protons as illustrated in Figure 3, while no correlations between $\mathrm{H}-1$ and $\mathrm{H}_{3}-14$, between $\mathrm{H}-5$ and $\mathrm{H}-11$, between $\mathrm{H}-5$ and $\mathrm{H}_{3}-12$, and between $\mathrm{H}-5$ and 

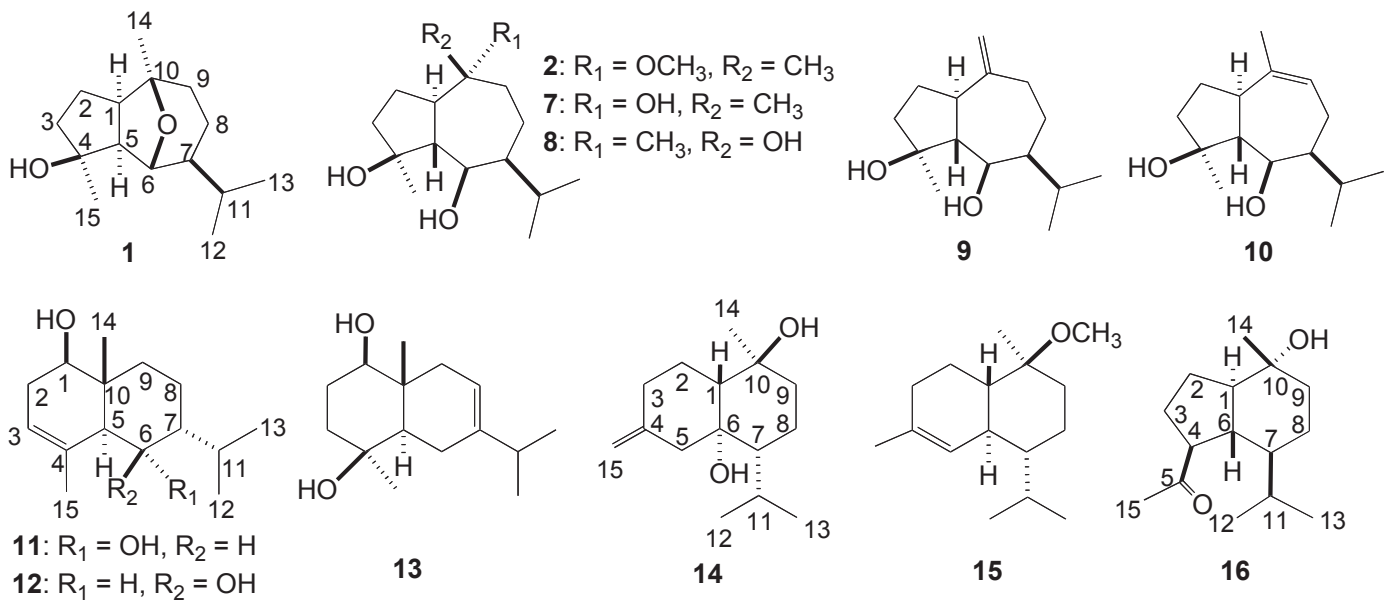

15

16
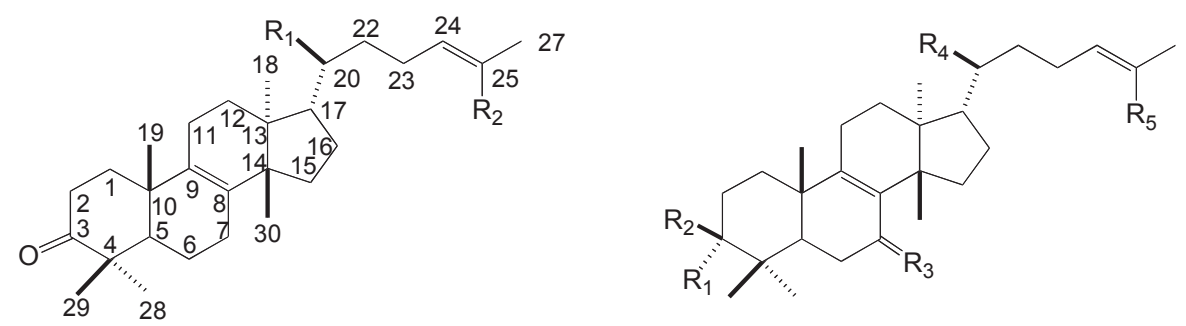

3: $\mathrm{R}_{1}=\mathrm{COOH}, \mathrm{R}_{2}=\mathrm{CH}_{3}$
4: $\mathrm{R}_{1}=\mathrm{CH}_{3}, \mathrm{R}_{2}=\mathrm{COOH}$

5: $\mathrm{R}_{1}=\mathrm{H}, \mathrm{R}_{2}=\mathrm{OH}, \mathrm{R}_{3}=\mathrm{H}_{2}, \mathrm{R}_{4}=\mathrm{CH}_{3}, \mathrm{R}_{5}=\mathrm{COOH}$

17: $\mathrm{R}_{1}=\mathrm{H}, \mathrm{R}_{2}=\mathrm{OH}, \mathrm{R}_{3}=\mathrm{H}_{2}, \mathrm{R}_{4}=\mathrm{COOH}, \mathrm{R}_{5}=\mathrm{CH}_{3}$

6: $\mathrm{R}_{1}=\mathrm{OH}, \mathrm{R}_{2}=\mathrm{H}, \mathrm{R}_{3}=\mathrm{O}, \mathrm{R}_{4}=\mathrm{CH}_{3}, \mathrm{R}_{5}=\mathrm{COOH}$

18: $\mathrm{R}_{1}=\mathrm{OH}, \mathrm{R}_{2}=\mathrm{H}, \mathrm{R}_{3}=\mathrm{H}_{2}, \mathrm{R}_{4}=\mathrm{CH}_{3}, \mathrm{R}_{5}=\mathrm{COOH}$

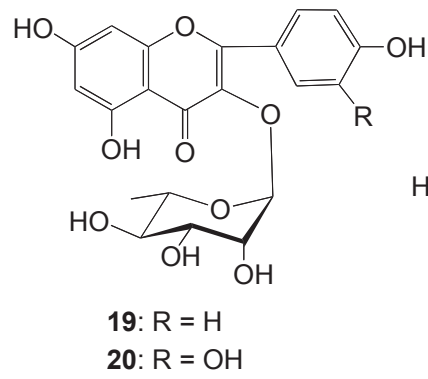<smiles>O=c1cc(-c2ccc(O)cc2)oc2c(-c3c(O)cc(Cl)c(CCl)c3O)c(O)cc(O)c12</smiles><smiles>O=C1CC(c2ccc(O)c(-c3c(O)cc(O)c4c3OC(c3ccc(O)cc3)CC4=O)c2)Oc2cc(O)cc(O)c21</smiles>

Fig. 1. Structures of $\mathbf{1}$ - 22.

$\mathrm{H}_{3}-13$ were detected; this suggested all of the configurations of $\mathrm{H}-1, \mathrm{H}-5$, and the methyl group at C-4 to be $\alpha$ and that of the isopropyl group at $\mathrm{C}-7$ to be $\beta$, and NOE correlations in the NOESY spectrum of 1a supported these configurations. Consequently, the structure of $\mathbf{1}$ was established as $6 \beta, 10 \beta$ epoxy-4 $\beta$-hydroxy- $1 \alpha, 5 \alpha, 7 \alpha(H)$-guaiane (Fig. 1). Recently, the structure of chrysothol was reported to be $6 \beta, 10 \beta$-epoxy$4 \alpha$-hydroxy-1 $\beta, 5 \alpha, 7 \beta(H)$-guaiane (Ahmed et al., 2006). However, the ${ }^{1} \mathrm{H}$ - and ${ }^{13} \mathrm{C}$-NMR data of $\mathbf{1 a}$ were superimposable on those of the monoacetate of chrysothol, and the sign and the value of the specific rotation of $\mathbf{1}$ was similar to those of chrysothol. Therefore, $\mathbf{1}$ was considered to be identical to chrysothol.

Compound 2 was obtained as a colorless syrup, $[\alpha]_{D}^{13}+$ $25.0^{\circ}\left(c=0.9, \mathrm{CHCl}_{3}\right)$. The positive FAB-MS and negative FAB-MS exhibited an $[\mathrm{M}+\mathrm{Na}]^{+}$ion peak at $\mathrm{m} / z 293$ and an [M-H] $]^{-}$ion peak at $\mathrm{m} / \mathrm{z} 269$, respectively. The HR-negative FAB-MS $(\mathrm{m} / \mathrm{z} 269.2100, \Delta-1.6 \mathrm{mmu})$ of 2 indicated the molecular formula of 2 to be $\mathrm{C}_{16} \mathrm{H}_{30} \mathrm{O}_{3}$. The ${ }^{1} \mathrm{H}$ - and ${ }^{13} \mathrm{C}-\mathrm{NMR}$ signals (Tables 1 and 2) of $\mathbf{2}$ were quite similar to those of $\mathbf{8}$, except for signals due to C-1, C-9, C-10, and C-14, and the appearance of signals due to one methoxyl group, although the assignments at $\mathrm{C}-1$ and $\mathrm{C}-7$ of $\mathbf{8}$ in the literature (Bruno et al., 1993) should be interchanged. From these data, 2 was considered to be a derivative of $\mathbf{8}$, in which a hydroxyl group at $\mathrm{C}-10$ was replaced by a methoxyl group. In the NOESY spectrum of 2, key NOEs were observed between H-1 and the methoxyl group, between $\mathrm{H}-5$ and $\mathrm{H}_{3}-14$, and between 


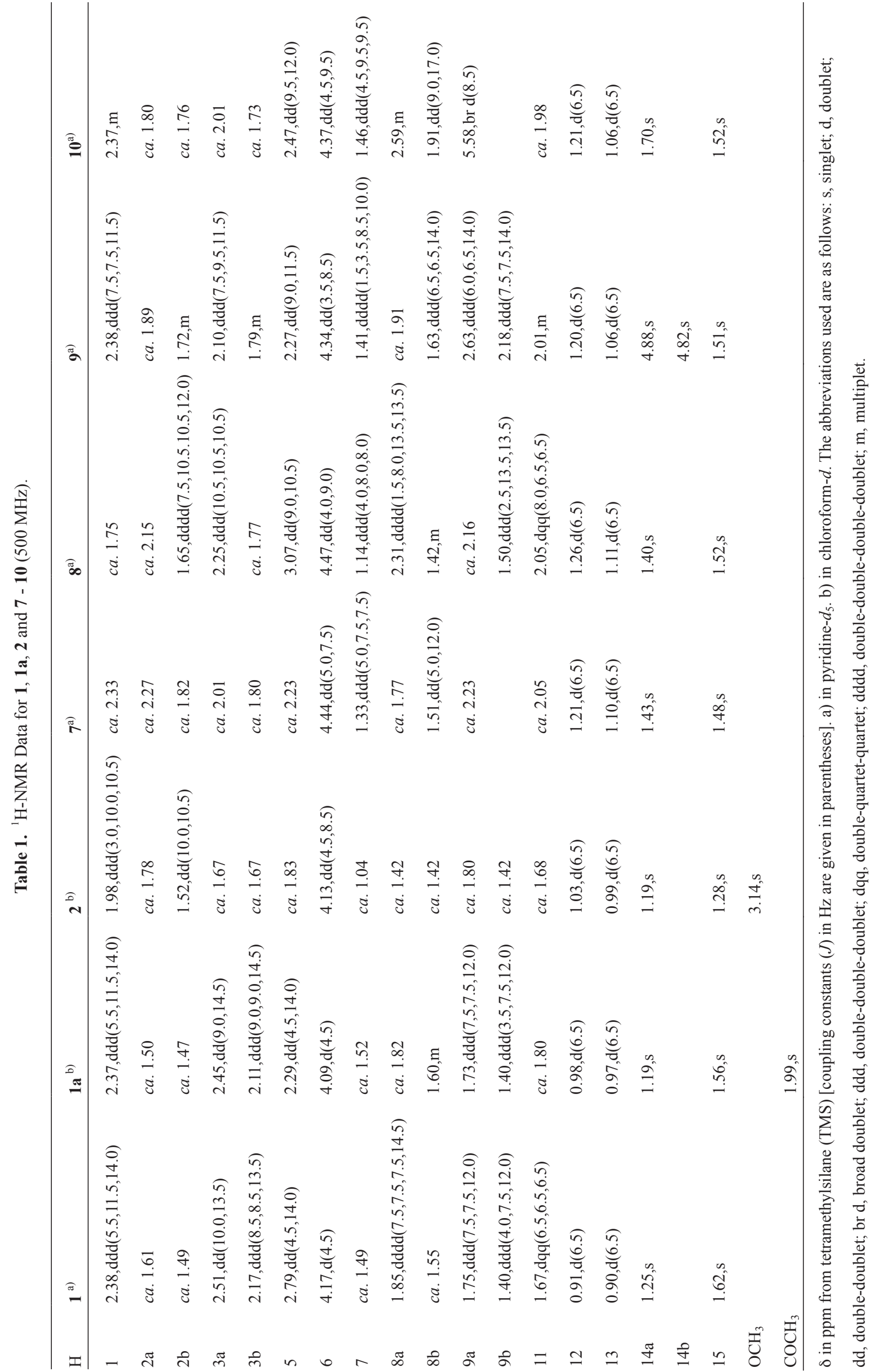


Table 2. ${ }^{13} \mathrm{C}-\mathrm{NMR}$ Data for 1, 1a, 2 and $\mathbf{7}-\mathbf{1 6}(125 \mathrm{MHz})$.

\begin{tabular}{lccccccccccccc}
\hline $\mathrm{C}$ & $\mathbf{1}^{\mathrm{a})}$ & $\mathbf{1 a}^{\mathrm{b})}$ & $\mathbf{2}^{\mathrm{b})}$ & $\mathbf{7}^{\mathrm{a})}$ & $\mathbf{8}^{\mathrm{a})}$ & $\mathbf{9}^{\mathrm{a})}$ & $\mathbf{1 0}^{\mathrm{a})}$ & $\mathbf{1 1}^{\mathrm{a})}$ & $\mathbf{1 2}^{\mathrm{a})}$ & $\mathbf{1 3}^{\mathrm{a})}$ & $\mathbf{1 4}^{\mathrm{a})}$ & $\mathbf{1 5}^{\mathrm{b})}$ & $\mathbf{1 6}^{\mathrm{a})}$ \\
\hline 1 & 53.3 & 52.5 & 42.1 & 46.5 & 45.9 & 43.2 & 42.8 & 76.9 & 76.4 & 79.7 & 55.4 & 46.6 & 57.9 \\
2 & 24.5 & 23.4 & 22.8 & 24.1 & 24.3 & 27.5 & 27.2 & 33.8 & 33.7 & 28.2 & 23.0 & 22.6 & 23.5 \\
3 & 48.8 & 46.5 & 41.2 & 41.9 & 41.7 & 41.4 & 40.8 & 121.8 & 121.9 & 40.6 & 35.6 & 30.9 & 29.0 \\
4 & 73.3 & 82.4 & 81.2 & 80.9 & 81.0 & 80.4 & 80.6 & 136.8 & 135.6 & 70.1 & 147.0 & 135.0 & 210.8 \\
5 & 69.1 & 66.6 & 54.9 & 56.2 & 54.0 & 60.6 & 58.3 & 50.8 & 51.9 & 47.3 & 47.4 & 122.5 & 56.0 \\
6 & 76.3 & 78.0 & 71.5 & 71.5 & 71.6 & 72.2 & 72.3 & 69.5 & 67.9 & 24.0 & 75.5 & 39.6 & 46.8 \\
7 & 38.7 & 37.9 & 51.9 & 52.5 & 52.5 & 49.2 & 51.0 & 46.5 & 50.2 & 142.6 & 52.6 & 46.7 & 49.9 \\
8 & 20.7 & 20.0 & 20.3 & 21.5 & 20.9 & 24.1 & 25.1 & 20.8 & 21.4 & 117.0 & 20.2 & 21.6 & 26.2 \\
9 & 37.9 & 37.3 & 40.7 & 49.0 & 48.1 & 36.8 & 126.7 & 34.7 & 37.1 & 41.7 & 44.2 & 35.5 & 43.0 \\
10 & 74.3 & 74.0 & 79.5 & 74.4 & 72.4 & 153.9 & 139.8 & 37.6 & 38.2 & 38.7 & 71.6 & 76.2 & 71.6 \\
11 & 33.3 & 32.4 & 29.6 & 30.6 & 30.5 & 29.9 & 29.3 & 27.7 & 29.4 & 35.4 & 25.6 & 26.0 & 29.8 \\
12 & 20.4 & 20.1 & 21.5 & 21.9 & 21.9 & 22.0 & 21.8 & 23.1 & 21.3 & 22.0 & 24.5 & 21.5 & 22.1 \\
13 & 21.2 & 21.1 & 21.2 & 21.4 & 21.5 & 21.7 & 21.6 & 21.8 & 21.2 & 21.4 & 19.0 & 15.2 & 16.0 \\
14 & 22.4 & 22.0 & 19.2 & 22.5 & 30.6 & 107.5 & 23.3 & 15.7 & 12.8 & 30.3 & 23.9 & 17.5 & 20.6 \\
15 & 26.6 & 21.7 & 23.1 & 23.6 & 23.8 & 24.3 & 24.5 & 23.3 & 20.8 & 12.6 & 100.8 & 23.8 & 29.3 \\
OCH $_{3}$ & & & 48.4 & & & & & & & & & 48.1 &
\end{tabular}

$\delta$ in ppm from TMS. a) in pyridine- $d_{5}$. b) in chloroform- $d$.

Table 3. ${ }^{1} \mathrm{H}-\mathrm{NMR}$ Data for $\mathbf{1 1} \mathbf{- 1 4}$ and $\mathbf{1 6}$ (in pyridine- $d_{5}, 500 \mathrm{MHz}$ ).

\begin{tabular}{|c|c|c|c|c|c|}
\hline $\mathrm{H}$ & 11 & 12 & 13 & 14 & 16 \\
\hline 1 & $3.87, \operatorname{dd}(6.5,10.0)$ & $3.84, \operatorname{dd}(6.5,10.0)$ & $3.63, \operatorname{dd}(3.5,12.5)$ & $1.72, \mathrm{dd}(2.5,12.5)$ & $1.74, \operatorname{ddd}(5.5,12.5,12.5)$ \\
\hline $2 \mathrm{a}$ & ca. 2.51 & $2.53, \mathrm{~m}$ & $2.51, \operatorname{dddd}(3.5,12.5,12.5,12.5)$ & $2.38, \mathrm{~m}$ & ca. 1.56 \\
\hline $2 b$ & $2.35, \mathrm{~m}$ & ca. 2.44 & $1.89, \operatorname{dddd}(3.5,3.5,3.5,12.5)$ & $1.81, \mathrm{~m}$ & ca. 1.56 \\
\hline $3 a$ & 5.46,br s & $5.53, \mathrm{br} \mathrm{s}$ & $1.99, \operatorname{ddd}(3.5,3.5,12.5)$ & 2.44, br d(12.5) & $1.89, \mathrm{~m}$ \\
\hline $3 b$ & & & $1.64, \operatorname{ddd}(3.5,12.5,12.5)$ & 2.08, $\operatorname{ddd}(4.5,12.5,12.5)$ & ca. 1.56 \\
\hline 4 & & & & & $2.63, \operatorname{ddd}(5.0,9.0,11.5)$ \\
\hline $5 \mathrm{a}$ & ca. 2.52 & $2.01, \mathrm{~s}$ & $1.41, \mathrm{dd}(5.0,12.5)$ & $2.75, \mathrm{~d}(13.0)$ & \\
\hline $5 b$ & & & & $2.00, \mathrm{~d}(13.0)$ & \\
\hline $6 a$ & $4.30, \operatorname{dd}(4.0,10.0)$ & $4.56, \mathrm{~s}$ & $c a .2 .64$ & & ca. 1.98 \\
\hline $6 b$ & & & $2.20, \operatorname{dd}(5.0,11.0)$ & & \\
\hline 7 & ca. 1.76 & ca. 0.99 & & 1.23, br d $(9.0)$ & ca. 1.13 \\
\hline $8 \mathrm{a}$ & ca. 1.76 & $1.88, \operatorname{dddd}(3.5,13.0,13.0,13.0)$ & $5.49, \mathrm{~d}(5.5)$ & ca. 1.84 & ca. 2.05 \\
\hline $8 \mathrm{~b}$ & ca. 1.76 & $1.76, \operatorname{dddd}(3.5,3.5,3.5,13.0)$ & & ca. 1.58 & ca. 1.52 \\
\hline $9 \mathrm{a}$ & ca. 1.94 & $2.44, \operatorname{ddd}(3.5,3.5,13.0)$ & $2.60, \operatorname{dd}(5.5,15.5)$ & ca. 2.13 & ca. 1.96 \\
\hline $9 b$ & ca. 1.94 & $1.34, \operatorname{ddd}(3.5,13.0,13.0)$ & 2.15, br d $(15.5)$ & ca. 1.84 & $1.66, \mathrm{~m}$ \\
\hline 11 & $2.17, \mathrm{~m}$ & $1.97, \mathrm{~m}$ & ca. 2.25 & $2.27, \mathrm{~m}$ & $1.66, \mathrm{~m}$ \\
\hline 12 & $1.25, \mathrm{~d}(6.5)$ & $1.09, \mathrm{~d}(6.5)$ & $1.06, \mathrm{~d}(6.5)$ & $1.10, \mathrm{~d}(6.5)$ & $0.89, \mathrm{~d}(7.0)$ \\
\hline 13 & $1.03, \mathrm{~d}(6.5)$ & $1.02, \mathrm{~d}(6.5)$ & $1.06, \mathrm{~d}(6.5)$ & $0.98, \mathrm{~d}(6.5)$ & $0.81, \mathrm{~d}(7.0)$ \\
\hline 14 & $1.24, \mathrm{~s}$ & $1.56, \mathrm{~s}$ & $1.58, \mathrm{~s}$ & $1.59, \mathrm{~s}$ & $1.33, \mathrm{~s}$ \\
\hline $15 \mathrm{a}$ & $2.23, \mathrm{~s}$ & $2.06, \mathrm{~s}$ & $1.37, \mathrm{~s}$ & $4.86, \mathrm{~s}$ & $2.16, \mathrm{~s}$ \\
\hline $15 b$ & & & & $4.74, \mathrm{~s}$ & \\
\hline
\end{tabular}

$\delta$ in ppm from TMS [coupling constants $(J)$ in $\mathrm{Hz}$ are given in parentheses]. The abbreviations used are as follows: s, singlet; br s, broad singlet; d, doublet; dd, double-doublet; br d, broad doublet; ddd, double-double-doublet; dddd, double-double-double-doublet; m, multiplet. 
Table 4. ${ }^{13} \mathrm{C}$-NMR Data for 3 - 6, 17 and $\mathbf{1 8}(125 \mathrm{MHz})$.

\begin{tabular}{|c|c|c|c|c|c|c|c|}
\hline $\mathrm{C}$ & $3^{\text {a) }}$ & $3^{\text {b) }}$ & $4^{\text {b) }}$ & $5^{\text {a) }}$ & $6^{\text {a) }}$ & $17^{\text {a) }}$ & $18^{\mathrm{a})}$ \\
\hline 1 & 35.7 & 35.4 & 35.6 & 35.9 & 29.5 & 35.9 & 30.5 \\
\hline 2 & 34.6 & 34.3 & 34.6 & 28.9 & 26.5 & 28.9 & 27.7 \\
\hline 3 & 216.4 & 217.7 & 218.1 & 78.1 & 74.1 & 78.1 & 75.0 \\
\hline 4 & 47.2 & 47.1 & 47.3 & 39.6 & 38.0 & 39.6 & 37.7 \\
\hline 5 & 51.5 & 51.4 & 51.6 & 51.5 & 42.8 & 51.5 & 45.1 \\
\hline 6 & 20.4 & 20.0 & 20.3 & 19.4 & 36.2 & 19.4 & 19.2 \\
\hline 7 & 27.3 & 27.3 & 27.5 & 28.1 & 197.8 & 27.5 & 27.0 \\
\hline 8 & 134.7 & 134.3 & 134.8 & 134.8 & 138.9 & 134.9 & 133.4 \\
\hline 9 & 133.2 & 132.5 & 132.8 & 133.7 & 166.2 & 133.6 & 135.2 \\
\hline 10 & 37.3 & 37.0 & 37.2 & 37.7 & 39.6 & 37.7 & 38.2 \\
\hline 11 & 21.6 & 21.2 & 21.4 & 21.8 & 23.6 & 21.8 & 21.8 \\
\hline 12 & 29.2 & 28.5 & 29.9 & 30.2 & 30.3 & 30.3 & 30.1 \\
\hline 13 & 44.5 & 43.8 & 44.2 & 44.5 & 44.9 & 44.6 & 44.4 \\
\hline 14 & 50.0 & 49.6 & 50.1 & 50.3 & 48.2 & 50.3 & 50.3 \\
\hline 15 & 29.8 & 29.2 & 30.8 & 31.2 & 32.3 & 31.5 & 31.2 \\
\hline 16 & 26.8 & 26.7 & 28.1 & 28.3 & 29.0 & 28.1 & 28.3 \\
\hline 17 & 47.5 & 46.8 & 50.2 & 50.5 & 49.2 & 46.9 & 50.4 \\
\hline 18 & 16.2 & 15.7 & 15.6 & 15.8 & 15.7 & 16.3 & 15.7 \\
\hline 19 & 19.7 & 19.5 & 19.8 & 20.5 & 18.6 & 20.5 & 20.4 \\
\hline 20 & 48.9 & 47.5 & 36.5 & 36.8 & 36.7 & 49.9 & 36.8 \\
\hline 21 & 178.6 & 182.4 & 18.6 & 18.9 & 19.0 & 178.3 & 18.9 \\
\hline 22 & 33.3 & 32.3 & 35.9 & 36.5 & 36.5 & 32.4 & 36.5 \\
\hline 23 & 26.7 & 25.8 & 26.9 & 27.1 & 27.0 & 26.9 & 27.0 \\
\hline 24 & 124.9 & 123.5 & 147.1 & 142.5 & 142.4 & 125.0 & 142.6 \\
\hline 25 & 131.7 & 131.9 & 125.8 & 128.7 & 128.8 & 131.8 & 128.6 \\
\hline 26 & 25.8 & 25.5 & 172.5 & 170.7 & 170.8 & 25.8 & 170.6 \\
\hline 27 & 17.7 & 17.5 & 20.5 & 21.5 & 21.5 & 17.8 & 21.5 \\
\hline 28 & 27.7 & 26.5 & 26.8 & 28.7 & 28.1 & 28.7 & 29.0 \\
\hline 29 & 21.2 & 21.0 & 21.1 & 16.5 & 22.0 & 16.5 & 22.7 \\
\hline 30 & 24.4 & 24.1 & 24.2 & 24.6 & 24.7 & 24.6 & 24.7 \\
\hline
\end{tabular}

$\delta$ in ppm from TMS. a) in pyridine- $d_{5}$. b) in chloroform- $d$.
H-6 and $\mathrm{H}_{3}-15$ (Fig. 3). Consequently, 2 was concluded to be $4 \beta, 6 \beta$-dihydroxy-10 $\alpha$-methoxy-1 $\alpha, 5 \beta, 7 \alpha(H)$-guaiane (Fig. $1)$.

Compound 3 was obtained as colorless needles $(\mathrm{MeOH})$, mp $222-223^{\circ} \mathrm{C},[\alpha]_{\mathrm{D}}^{14}+35.4^{\circ}\left(c=2.7, \mathrm{CHCl}_{3}\right)$, and indicated an $[\mathrm{M}]^{+}$ion peak at $m / z 454$ in the electron impact (EI)-MS. The ${ }^{1} \mathrm{H}-\mathrm{NMR}$ spectrum (in pyridine- $d_{5}$ ) of $\mathbf{3}$ showed signals due to one olefinic proton $[\delta 5.34(\mathrm{dd}, J=6.0,6.0 \mathrm{~Hz})]$ and seven tertiary methyl groups $(\delta 1.68,1.63,1.15,1.09,1.05$, $0.97,0.94)$. The ${ }^{13} \mathrm{C}$-NMR spectrum of 3 gave 30 carbon signals, including two carbonyl carbons $(\delta 216.4,178.6)$ and four olefinic carbons $(\delta 134.7,133.2,131.7,124.9)$. From these data, $\mathbf{3}$ was assumed to be a tirucallane- or euphane -type triterpenoid, which was previously isolated from this plant. Finally, the structure of $\mathbf{3}$ was elucidated by X-ray crystallography (Fig. 4, Table 6). Consequently, the structure of 3 was confirmed as 3-oxo-8,24-tirucalladien-21-oic acid, which was previously isolated from Boswellia carterii Birdwood (Badria et al., 2003) (Fig. 1). However, the assignment of ${ }^{13} \mathrm{C}-\mathrm{NMR}$ data (in chloroform- $d$ ) in the literature (Badria et al., 2003) should be corrected as shown in Table 4, and ${ }^{1} \mathrm{H}$ - and ${ }^{13} \mathrm{C}$-NMR data in pyridine- $d_{5}$ have not been reported.

Compound 4 was obtained as a white powder, $[\alpha]_{\mathrm{D}}^{14}+$ $13.2^{\circ}\left(c=1.4, \mathrm{CHCl}_{3}\right)$, and showed the same $[\mathrm{M}]^{+}$ion peak as that of 3 at $m / z 454$ in the EI-MS. The ${ }^{1} \mathrm{H}$ - and ${ }^{13} \mathrm{C}-\mathrm{NMR}$ signals were similar to those of $\mathbf{3}$, except for signals due to $\mathrm{C}-17$ and the side chain moiety, which were quite similar to those of $\mathbf{1 8}$ (Olfasson, 1997) (Tables 4 and 5). Thus, $\mathbf{3}$ was identified as isomasticadienoic acid (Paraschos, 2007) (Fig. 1). Recently, the ${ }^{13} \mathrm{C}-\mathrm{NMR}$ data of $\mathbf{3}$ have been reported (Paraschos, 2007), although the assignments in the literature

Table 5. ${ }^{1} \mathrm{H}-\mathrm{NMR}$ Data for $\mathbf{3}$ - 5, 17 and $\mathbf{1 8}(500 \mathrm{MHz})$.

\begin{tabular}{rlllll}
\hline $\mathrm{H}$ & $\mathbf{3}^{\mathrm{a})}$ & $\mathbf{4}^{\mathrm{a})}$ & $\mathbf{5}^{\mathrm{b})}$ & $\mathbf{1 7}^{\mathrm{b})}$ & $\mathbf{1 8}^{\mathrm{b})}$ \\
\hline 3 & & & $3.47, \mathrm{dd}(5.5,10.5)$ & $3.48, \mathrm{dd}(5.5,11.0)$ & $3.63, \mathrm{br} \mathrm{s}$ \\
18 & $0.82, \mathrm{~s}$ & $0.76, \mathrm{~s}$ & $0.85, \mathrm{~s}$ & $0.97, \mathrm{~s}$ & $0.97, \mathrm{~s}^{\mathrm{c})}$ \\
19 & $1.03, \mathrm{~s}$ & $1.05, \mathrm{~s}$ & $1.04, \mathrm{~s}$ & $1.04, \mathrm{~s}$ & $1.05, \mathrm{~s}$ \\
21 & & $0.93, \mathrm{~d}(6.0)$ & $1.05, \mathrm{~d}(6.0)$ & & $1.01, \mathrm{~d}(6.0)$ \\
24 & $5.09, \mathrm{dd}(5.0,5.0)$ & $6.09, \mathrm{dd}(7.5,7.5)$ & $6.06, \mathrm{dd}(7.5,7.5)$ & $5.37, \mathrm{dd}(7.5,7.5)$ & $6.03, \mathrm{dd}(7.0,7.0)$ \\
26 & $1.58, \mathrm{~s}$ & & & $1.65, \mathrm{~s}$ & \\
27 & $1.67, \mathrm{~s}$ & $1.92, \mathrm{~s}$ & $2.14, \mathrm{~s}$ & $1.67, \mathrm{~s}$ & $2.12, \mathrm{~s}$ \\
28 & $1.09, \mathrm{~s}$ & $1.10, \mathrm{~s}$ & $1.07, \mathrm{~s}$ & $1.07, \mathrm{~s}$ & $1.21, \mathrm{~s}$ \\
29 & $1.05, \mathrm{~s}$ & $1.06, \mathrm{~s}$ & $1.25, \mathrm{~s}$ & $1.25, \mathrm{~s}$ & $0.93, \mathrm{~s}^{\mathrm{c})}$ \\
30 & $0.91, \mathrm{~s}$ & $0.89, \mathrm{~s}$ & $0.94, \mathrm{~s}$ & $0.96, \mathrm{~s}$ & $0.94, \mathrm{~s}^{\mathrm{c})}$ \\
\hline
\end{tabular}

$\delta$ in ppm from TMS [coupling constants $(J)$ in Hz are given in parentheses]. a) in chloroform- $d$. b) in pyridine- $d_{5}$. c) Assignments may be interchanged. The abbreviations used are as follows: s, singlet; br s, broad singlet; d, doublet; dd, double-doublet. 

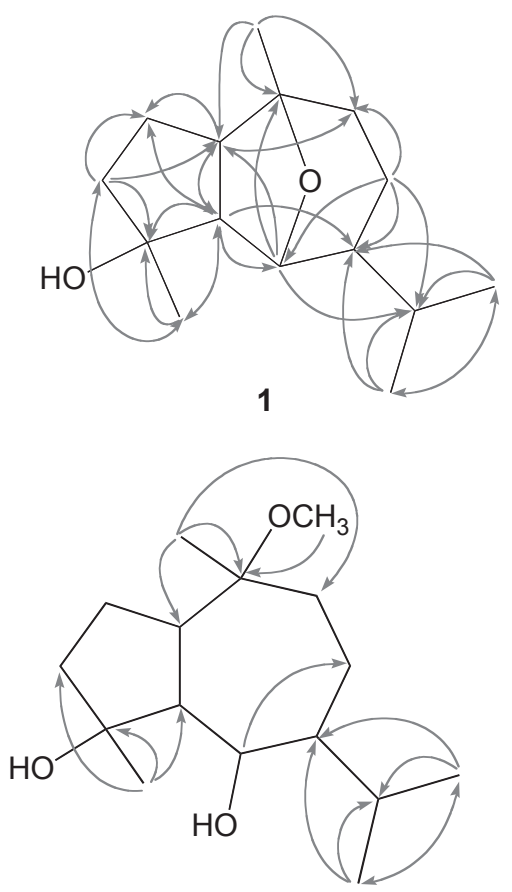

2

HMBC: $\mathrm{H} \cap \mathrm{C}$

Fig. 2. ${ }^{1} \mathrm{H}-{ }^{13} \mathrm{C}$ long-range correlations observed for $\mathbf{1}$ (in pyridine- $d_{5}$ ) and 2 (in chloroform- $d$ ) in the HMBC spectra $(500 \mathrm{MHz})$.

should be corrected as shown in Table 4 .

Compound 5 was obtained as a white powder, $[\alpha]_{\mathrm{D}}^{24}-$ $8.1^{\circ}\left(c=1.0, \mathrm{CHCl}_{3}\right)$, and was determined to have the molecular formula $\mathrm{C}_{30} \mathrm{H}_{48} \mathrm{O}_{3}$ by HR-EI-MS ( $\mathrm{m} / z$ 456.3596, $\Delta$ - $1.7 \mathrm{mmu}$ ). The ${ }^{1} \mathrm{H}$ - and ${ }^{13} \mathrm{C}$-NMR signals were similar to those of 4, except for the appearance of a signal due to one oxygenated methine group $\left[\delta_{\mathrm{H}} 3.47(1 \mathrm{H}, \mathrm{dd}, J=5.5,10.5\right.$ $\left.\mathrm{Hz}), \delta_{\mathrm{C}} 78.1\right]$, the loss of a signal due to one ketone carbonyl carbon, and the resonances of signals due to an A-ring moiety (Tables 4 and 5). From these data, $\mathbf{5}$ was identified as 24Z-isomasticadienolic acid. Although the ${ }^{1} \mathrm{H}-\mathrm{NMR}$ spectral data of methyl ester of $\mathbf{5}$ was previously reported (PozzoBalbi et al., 1978), ${ }^{1} \mathrm{H}$ - and ${ }^{13} \mathrm{C}-\mathrm{NMR}$ data of 5 have not been reported the literature.

Compound $\mathbf{6}$ was obtained as a white powder. In the EIMS, 6 gave an $[\mathrm{M}]^{+}$ion peak at $m / z$ 456. The ${ }^{1} \mathrm{H}$ - and ${ }^{13} \mathrm{C}$ NMR signals were imposable on those of $\mathbf{1 8}$, with an additional signal due to one ketone carbonyl carbon and the loss of a signal due to one methylene group; the ${ }^{13} \mathrm{C}$-NMR data due to a side chain moiety was almost same as those of $\mathbf{1 8}$ (Tables 4 and 5). The location of a ketone carbonyl carbon was confirmed by techniques similar to those of $\mathbf{1}$. Consequently, 6 was elucidated as 7,11-dioxo-3 $\alpha$-hydroxy-8,24Z-
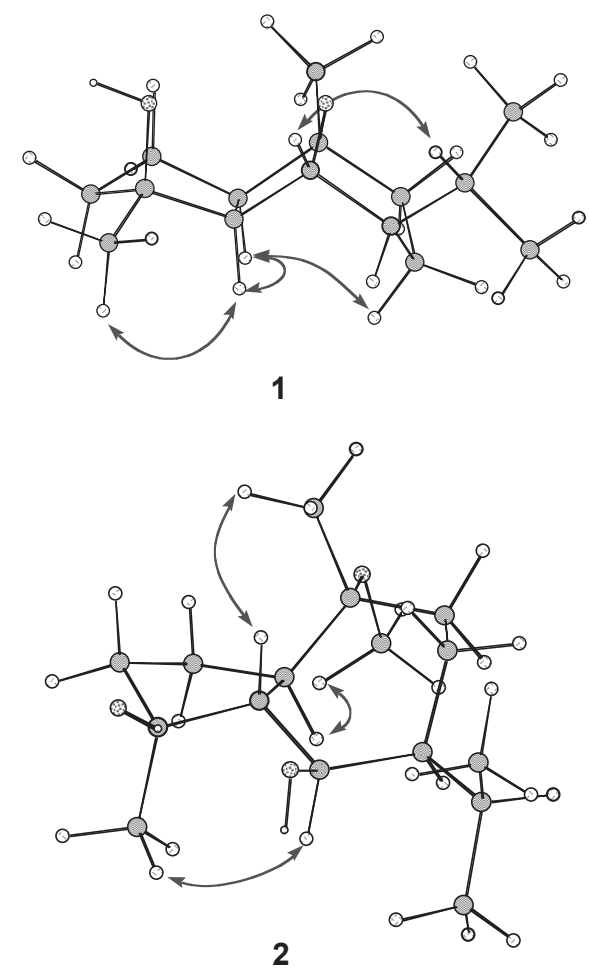

NOE:

Fig. 3. Selected NOE correlations observed for $\mathbf{1}$ (in pyridine- $d_{5}$ ) and 2 (in chloroform- $d$ ) (500 MHz).

tirucalladien-26-oic acid (Fig. 1), which has been recently reported as a constituent of Juliania adstringens, and its ${ }^{1} \mathrm{H}-$ NMR data were quite similar to those of $\mathbf{6}$, but the ${ }^{13} \mathrm{C}$-NMR data were slightly different from those of $\mathbf{6}$ (Makino et al., 2004).

Antioxidative effect of 19 - 22 The antioxidative activity of 19 - 22 was evaluated using linoleic acid as the substrate in the ferric thiocyanate method. Compounds 19, 20, and 21 exhibited almost the same activity as that of $\alpha$-tocopherol (Fig. 5). Furthermore, the scavenging effect of 19 - 22 on the stable free radical DPPH was examined. Compound $\mathbf{2 0}$ exhibited more potent activity than $\alpha$-tocopherol at a concentration of $0.02 \mathrm{~mm}$ (Fig. 6).

In conclusion, 12 sesquiterpenoids, one of which was a new compound (2), six tirucallane-type triterpenoids and four flavonoids were isolated from the fruits of S. molle. Tirucallane- and euphane-type triterpenoids, a sesquiterpenoid, and a biflavonoid have been previously isolated from the fruits of S. molle (Terhune et al., 1974; Pozzo-Balbi et al., 1978; Olfasson et al., 1997; Yueqin et al., 2003), but this is the first report on the isolation of $\mathbf{1}, \mathbf{3}, \mathbf{5}-\mathbf{1 7}$, and $19-22$ from the fruits. Yokozawa et al. (1998) reported that the 3,4-dihydroxyl group in the B-ring of the flavonoid skeleton is important for 


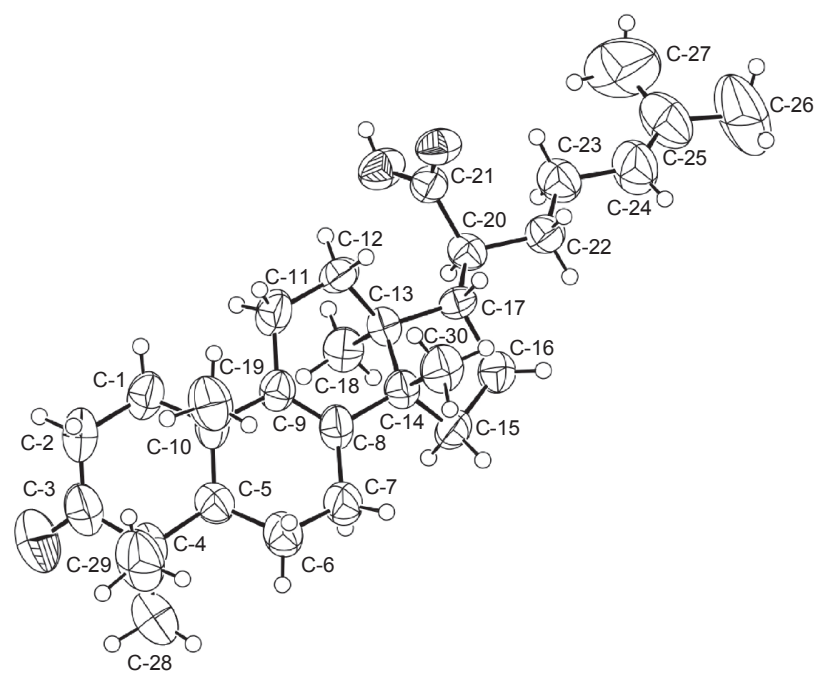

Fig. 4. ORTEP drawing of 3 . The ellipsoid probability level of 3 is $50 \%$.

Table 6. Crystal Data and Intensity Measurement of $\mathbf{3}$.

\begin{tabular}{ll}
\hline formula & $\mathrm{C}_{30} \mathrm{H}_{46} \mathrm{O}_{3}$ \\
formula weight & 454.67 \\
crystal system & orthorhombic \\
lattice parameters & \\
$a(\AA)$ & $7.0807(9)$ \\
$b(\AA)$ & $9.9782(14)$ \\
$c(\AA)$ & $39.079(5)$ \\
$V\left(\AA^{3}\right)$ & $2761.1(6)$ \\
space group & $P 2_{1} 2_{1} 2_{1}(\# 19)$ \\
$Z$ & 4 \\
$D c\left(\mathrm{~g} / \mathrm{cm}^{3}\right)$ & 1.09 \\
unique data used $(I>2.0 \sigma I)$ & 6289 \\
$R$ & 0.089 \\
$R w$ & 0.185 \\
\hline
\end{tabular}

the DPPH radical-scavenging effect. The results in this study supported this structure-activity relationship, because $\mathbf{2 0}$ showed a higher effect than those of 19, 21, and $\mathbf{2 2}$.

Acknowledgments We express our appreciation to Mr. K. Takeda and Mr. T. Iriguchi of Kumamoto University for their measurement of the MS and NMR spectra. This research was supported in part by a Grant-in-Aid for Scientific Research (C) (No. 19590030) from the Japan Society for the Promotion of Science.

\section{References}

Ahmad, I., Ishratullah, K., Ilyas, M., Rahman, W., Seligmann, O. and Wagner, H. (1981). Tetrahydroamentoflavone from nuts of

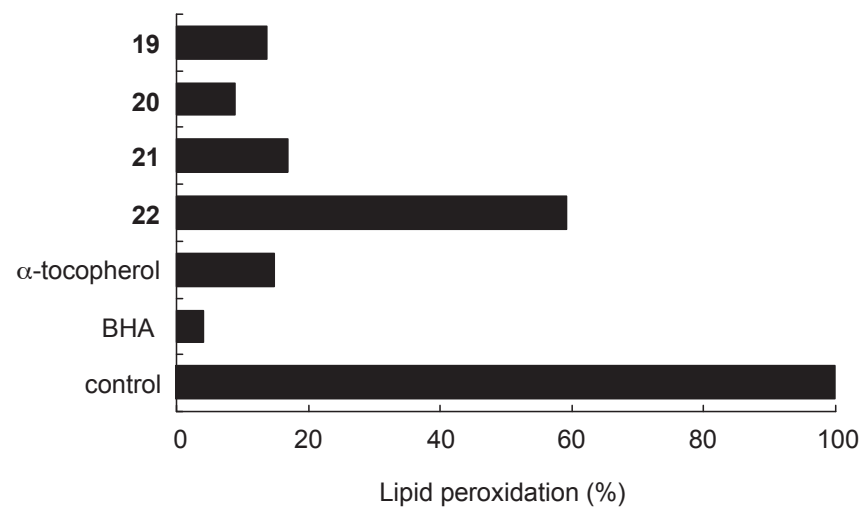

Fig. 5. Antioxidative activity of $\mathbf{1 9}$ - 22, $\alpha$-tocopherol and BHA after the fifth day of lipid peroxidation. The final concentration of the sample was $0.5 \mathrm{~mm}$. The value of control represents $100 \%$ lipid peroxidation.

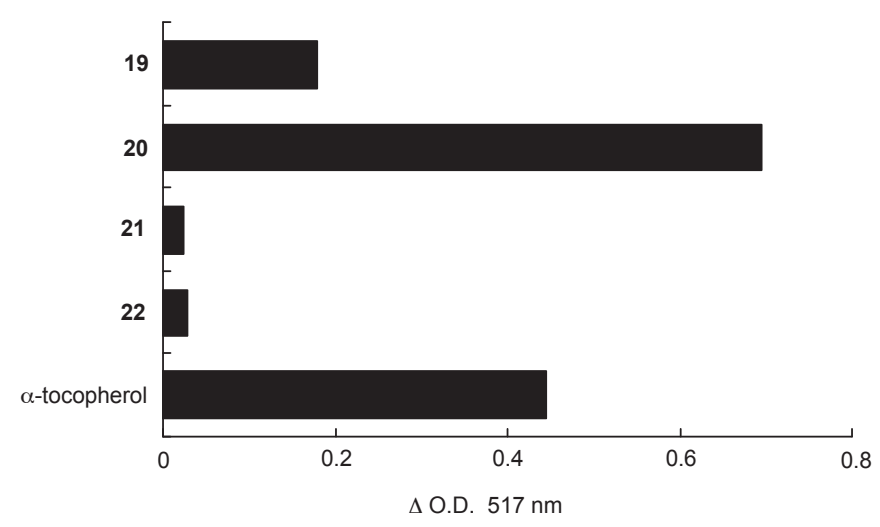

Fig. 6. DPPH radical-scavenging effect of 19 - 22 and $\alpha$-tocopherol. The final concentration of each sample tested was $0.02 \mathrm{~mm}$. $\Delta$ O. D. $=$ O. D. of control at $517 \mathrm{~nm}(1.115)-\mathrm{O}$. D. of sample.

Semecarpus prainii. Phytochemistry, 20, 1169 - 1170.

Ahmed, A.A., Hegazy, M.F., Hassan, N.M., Wojcinska, M., Karchesy, J., Pare, P.W. and Mabry, T.J. (2006). Constituents of Chrysothamnus viscidiflorus. Phytochemistry, 67, 1547 - 1553.

Badria, F.A., Mikhaeil, B.R., Maatooq, G.T. and Amer, M.M.A. (2003). Immunomodulatory triterpenoids from olegum resin of Boswellia carterii Birdwood. Zeitschrift für Natuforschung, 58c, 505 - 516.

Bruno, M., de la Torre, M.C., Rodreíguez, B. and Omar, A.A. (1993). Guaiane sesquiterpenes from Teucrium leucocladum. Phytochemistry, 34, 245 - 247.

Chari, V.M., Ilyas, M., Wagner, H., Neszmélyi, A., Chen, F., Chen, L., Lin, Y. and Lin, Y. (1977). ${ }^{13}$ C-NMR spectroscopy of biflavonoids. Phytochemistry, 16, 1273 - 1278.

Dupré, S., Grenz, M., Jakupovic, J., Bohlmann, F. and Niemeyer, H.M. (1991). Eremophilane, germacrane, and shikimic acid derivatives from Chilean senecio species. Phytochemistry, 30, 1211 -1220 . 
Harbone, J.B. and Mabry, T.J. (1982). In "The Flavonoids: Advances in Research". New York: Chapman and Hall, p. 93.

Herz, W. and Watanabe, K. (1983). Sesquiterpene alcohols and triterpenoids from Liatris microcephala. Phytochemistry, 22, 1457 1459.

Kikuzaki, N. and Nakatani, N. (1993). Antioxidant effects of some ginger constituents. J. Food. Sci., 58, 1407 - 1410.

Mahmoud, A.A. (1997). 7-Epi-eudesmanes, eudesmanoic acids, eudesmanolides, and other sesquiterpenes from Pluchea dioscoridis. Phytochemistry, 45, 1633 - 1638.

Makino, M., Motegi, T. and Fujimoto, Y. (2004). Tirucallane-type triterpenes from Juliania adstringenus. Phytochemistry, 65, 891 896.

Nawamaki, K. and Kuroyanagi, M. (1996). Sesquiterpenoids from Acorus calamus as germination inhibitors. Phytochemistry, 43, 1175 - 1182.

Olfasson, K., Jaroszewski, J.W., Smitt, U.W. and Nyman, U. (1997). Isolation of angiotensin converting enzyme (ACE) inhibiting triterpenes from Schinus molle. Planta Med., 63, 352 - 355.

Ono, M., Oda, E., Tanaka, T., Iida, Y., Yamasaki, T., Masuoka, C., Ikeda, T. and Nohara, T. (2008). DPPH radical-scavenging effect on some constituents from the aerial parts of Lippia triphylla. J. Nat. Med., 62, 101 - 106.

Paraschos, S., Magiatis, P., Mitakou, S., Petraki, K., Kalliaropoulos, A., Maragkoudakis, P., Mentis, A., Sgouras, D. and Skaltsounis, A. (2007). In vitro and in vivo activities of Chios mastic gum extracts and constituents against Helicobacter pylori. Antimicrob. Agents Chemother, 51, 551 - 559.

Pozzo-Balbi, T., Nobile, L., Scapini, G. and Cini, M. (1978). The triterpenoid acids of Schinus molle. Phytochemistry, 17, 2107 2110.

Sheldrick, G. M. (1990). Phase annealing in SHELX-90: direct methods for larger structures. Acta Cryst., A46, 467 - 473.

Sheldrick, G.M. and Schneider, T.R. (1997). SHELXL: High resolution refinement. In Methods in Enzymology, 277, edited by C. W. Carter, Jr. \& R. M. Sweet. San Diego: Academic Press, pp. 319 343.

Silva, D.H.S., Yoshida, M. and Kato, M.J. (1997). Flavonoids from Iryanthera sagotiana. Phytochemistry, 46, 579 - 582.

Takahashi, K. and Takani, M. (1976). Studies on constituents of medicinal plants. XVII. Constituents of Schizandra nigra Max. and their carbon-13 nuclear magnetic resonance spectra (2). Chem. Pharm. Bull., 24, 2000 - 2006.

Terhune, S.J. Hogg, J.W. and Lawrence, B.M (1974). Essential oils and their constituents. XV. $\beta$-Spathulene. New sesquiterpene in Schinus molle oil. Phytochemistry, 13, 865 - 866.

Uchiyama, M., Suzuki, Y. and Fukuzawa, K. (1968). Biochemical studies of physiological function of tocopheronolactone.1. Yakugaku Zasshi, 88, 678 - 683 (in Japanese).

Yokozawa, T., Chen, C.P., Dong, E., Tanaka, T., Nonaka, G. and Nishioka, I. (1998). Study on the inhibitory effect of tannins and flavonoids against the 1,1-diphenyl-2-picrylhydrazyl radical. Biochem. Pharmacol., 56, 213 - 222.

Yueqin, Z., Recio, M.C., Máñez, S., Giner, R.M., Cerdá-Nicolás, M. and Ríos, J. (2003). Isolation of two triterpenoids and a biflavone with anti-inflammatory activity from Schinus molle fruits. Planta Med., 69, 893 - 898. 